\title{
REVIEW
}

\section{IGFs and IGF-binding proteins in the regulation of human ovarian and endometrial function}

\author{
H-S Wang and T Chard ${ }^{1}$ \\ Department of Obstetrics and Gynecology, Chang-Gung Memorial Hospital, Lin-Kou Medical Center, Taipei, Taiwan, Republic of China and ${ }^{1}$ Department of \\ Obstetrics and Gynaecology (Reproductive Physiology Laboratory), St Bartholomew's Hospital, West Smithfield, London EC1A 7BE, UK \\ (Requests for offprints should be addressed to H-S Wang)
}

\section{Introduction}

The key function of reproduction is to propagate inheritable characteristics to new generations. The human female reproductive system consists of the hypothalamicpituitary-ovarian axis and end organs such as the uterus and fallopian tubes. The endocrine axis involves both peptide hormones (gonadotropin-releasing hormone, follicle-stimulating hormone (FSH) and luteinizing hormone (LH)) and steroid hormones (estradiol and progesterone). In addition, numerous growth factors, including the insulin-like growth factors (IGFs) and IGFbinding proteins (IGFBPs), play an important role at the tissue and cellular level through autocrine and/or paracrine mechanisms. There is substantial evidence that IGFs and IGFBPs are involved in follicular growth/development and steroidogenesis in the ovary, in proliferation and differentiation of the uterine endometrium, and in the implantation of the embryo.

\section{IGFs and IGFBPs}

IGF-I and IGF-II are single-chain polypeptides with molecular masses of $7649 \mathrm{Da}$ and $7471 \mathrm{Da}$ respectively (Rinderknecht \& Humbel 1978a,b). Both IGFs are structurally homologous to proinsulin and have insulinlike metabolic effects (induced hypoglycemia) (Guler et al. 1987). The hypoglycemic effects induced by the IGFs are mediated via the insulin receptor since IGFs at high concentrations bind insulin receptors (Froesch \& Zapf 1985). IGFs are synthesized de novo in a variety of tissues and exert mitogenic effects within the local tissue environment through autocrine and/or paracrine mechanisms (Holly \& Wass 1989). In addition to their roles as mitogens, IGF-I and IGF-II induce cellular differentiation and promote the expression of differentiated functions in a variety of cells (Florini et al. 1991, Quinn et al. 1993, Jones \& Clemmons 1995). IGF-I is growth hormone (GH) dependent and mainly produced by the liver (Schwander et al. 1983). Two major classes of IGF-I mRNA transcripts have been identified in the liver and in non-hepatic tissues; both transcripts code for the same mature peptide (LeRoith \& Roberts 1991). 'Exon 2 transcripts' of IGF-I (mRNAs containing a $5^{\prime}$-untranslated region starting in exon 2) are believed to encode the 'endocrine form of IGF-I' under the control of GH in the liver. 'Exon 1 transcripts' of IGF-I (mRNAs containing a $5^{\prime}$-untranslated region starting in exon 1), which are found in all tissue, are regulated by factors other than $\mathrm{GH}$ and may represent the 'autocrine/paracrine form of IGF-I' (LeRoith \& Roberts 1991). In contrast to IGF-I, IGF-II is not strongly GH dependent (Zapf et al. 1981). IGF-II has no growthpromoting effect in the hypophysectomized rat (Brown et al. 1986). In the rodent and a number of other species, IGF-II is thought to function as a fetal growth factor since IGF-II gene deletion results in retardation of intrauterine and perinatal growth (Schoenle et al. 1985, DeChiara et al. 1990). The role of IGF-II in man, however, remains controversial.

The biological effects of IGFs are mediated through two types of cell membrane receptor (Rosenfeld 1989, Nissley \& Lopaczynski 1991). The type I receptor is composed of two extracellular $\alpha$-subunits and two transmembrane $\beta$-subunits (Jones \& Clemmons 1995). Type I receptors preferentially bind IGF-I and also bind insulin at high concentrations (Nissley \& Lopaczynski 1991). The binding affinity of type I receptors is: IGF-I $\geqslant$ IGF-II >> insulin. In contrast, type II receptors bind only IGFs and preferentially bind IGF-II (binding affinity of type II receptors: IGF-II >>IGF-I) (Table 1). Structurally, the type II receptor is a monomeric receptor identical to the mannose-6phosphate receptor (Morgan et al. 1987). Functionally, most of the actions of both IGF-I and IGF-II are mediated by the type I receptor. In non-mammalian species, IGFII does not bind to the mannose-6-phosphate receptor (Clairmont \& Czech 1989). In the human, both type I and type II receptors have been identified in a wide range of tissues including ovarian follicles (Hernandez et al. 1992), the endometrium (Ghahary \& Murphy 1989) and the 
Table 1 The binding affinity between insulin, IGFs and their receptors (Rosenfeld 1989, Nissley \& Lopaczynski 1991)

\begin{tabular}{|c|c|c|c|}
\hline & Type I receptor & Type II receptor & Insulin receptor \\
\hline IGF-I & High & Vey low & Very low \\
\hline |GF-I| & High or intermediate & High & Low \\
\hline Insulin & Very low & None & High \\
\hline
\end{tabular}

placenta (Han et al. 1996, Liu et al. 1996, Sakai et al. 1997). However, fetal tissues have greater type I and type II IGF binding activities than adult tissues (Ocrant et al. 1988).

The most specific characteristic of IGFs, distinguishing them from other growth factors, is that they are regulated and modulated by a heterogeneous group of binding proteins (IGFBPs) with molecular masses ranging from 17 to $43 \mathrm{kDa}$ (Binoux et al. 1991, Cataldo 1997). These high-affinity IGFBPs can compete with the IGF receptor for binding. The physiological roles of IGFBPs include prevention of the hypoglycemic response of IGFs (Yoeh \& Baxter 1988), prolongation of clearance time of IGFs (Guler et al. 1989), transportation of IGFs to appropriate sites of action and modulation (e.g. enhancement or inhibition) of the action of IGFs (Busby et al. 1988, Bar et al. 1989). To date, six binding proteins (IGFBP-1 to IGFBP-6) have been identified and characterized. In the circulation, IGFBP-3 is the major carrier protein for the IGFs. This is supported by the fact that IGFBP-3 (as large molecular mass ' $150 \mathrm{kDa}$ ' complexes containing IGFBP-3, IGF and the acid labile subunit) is unable to cross the capillary barrier and is retained in the circulation (Binoux et al. 1991). In contrast, IGFBP-1 is believed to regulate acute changes of serum IGFs (Wang \& Chard 1992, Lee et al. 1997). Additionally, IGFBP-1 can cross the capillary barrier (Binoux et al. 1991) and modulate (e.g. enhance or inhibit) the actions of IGFs at the cellular level (Straus et al. 1991). The phosphorylation of IGFBP-1 may affect IGF actions; non-phosphorylated IGFBP-1 has 4- to 6-fold lower affinity for IGF-I as compared with phosphorylated IGFBP-1 (Jones et al. 1991). Thus, more complete release of IGF-I to receptors would be achieved by non-phosphorylated IGFBP-1. In contrast, the phosphorylated form of IGFBP-1 is more likely to sequestrate IGF-I and in turn attenuate the actions of IGF-I. IGFBP-2 has been much less extensively studied than IGFBP-1. In general, IGFBP-2 is thought to inhibit IGF actions, particularly those of IGF-II (Reeve et al. 1993), although in certain specific cell types it can be a modest stimulator of IGF-I action (Bar et al. 1989). In addition, IGFBP-2, as with IGFBP-1, appears to be the major binding protein for IGF-I in the human fetus (Wang \& Chard 1992). IGFBP-4 and IGFBP-5 are involved in the control of growth in bone and cartilage (Mohan et al. 1989, Kiefer et al. 1992), as well as folliculogenesis and steroidogenesis in the rat ovary (Ling et al. 1993, Erickson et al. 1994).
IGFBP-5 has the unique property of adhering tightly to fibroblast extracellular matrix (ECM). The affinity of IGFBP-5 for IGF-I is lowered by approximately 7-fold when it associates with ECM, suggesting that ECMbound IGFBP-5 may potentiate IGF actions (Jones et al. 1993a). As with IGFBP-4 and IGFBP-5 in the rat ovary, IGFBP-6, stimulated by combined FSH and LH, is also associated with decreased steroidogenesis in response to IGF-I (Rohan et al. 1993). However, these effects are substantially weaker than those of IGFBP-4 and IGFBP-5.

Proteolysis of IGFBP-2, IGFBP-3 and IGFBP-4 is a posttranslational processing mechanism that might affect the actions of these binding proteins. In a wide variety of tissues, protease activity may specifically cleave IGFBPs into smaller molecular weight forms that have a markedly reduced affinity for IGFs and in turn potentiate IGF actions (Schmid et al. 1991, Conover et al. 1993, Mason et al. 1996). Thus, proteolytic activity may be an important mechanism by which bioactive IGFs are made available to specific tissues. IGFBP-5 is also cleaved by proteases to a smaller fragment. However, unlike IGFBP-2, IGFBP-3 and IGFBP-4, the smaller fragment of IGFBP-5 does not potentiate the cell growth response to IGF-I (Jones et al. 1993a).

\section{IGFs and IGFBPs in the ovary}

\section{Follicular growth and development}

There is evidence that a tissue-specific and temporal pattern of expression of the IGFs is involved in the development of ovarian follicles (Erickson et al. 1994). Studies of the cellular sites of IGF gene expression have shown that, in the rat, IGF-I and IGF-II mRNA are localized to the granulosa cells (Carlsson et al. 1989, Hernandez et al. 1989, Oliver et al. 1989, Zhou et al. 1991) and theca-interstitial cells (Hernandez et al. 1990) respectively. The granulosa cells begin to express IGF-I during the early follicular phase and a high level of IGF-I activity is detected in the granulosa cells of healthy follicles. In contrast, expression of IGF-I mRNA is not observed in atretic follicles (Carlsson et al. 1989, Hernandez et al. 1989, Oliver et al. 1989, Zhou et al. 1991). These findings suggest that, in the rat, selection of the dominant follicle requires continual expression of IGF-I in the granulosa cells. 
In the human ovary, the granulosa cell is a site of IGF-II rather than IGF-I gene expression (Hernandez et al. 1992, El Roeiy et al. 1993, Zhou \& Bondy 1993, Mason et al. 1994). The concentrations of IGF-II (but not IGF-I) are significantly higher in ovarian venous effluents as compared with the peripheral circulation, implying an ovarian source for this peptide (Jesionowska et al. 1990). In contrast, IGF-I mRNA is not detected in granulosa cells of the mature human ovary, while IGF-I receptor mRNA is abundant in granulosa cells of both Graafian and atretic follicles (El Roeiy et al. 1993, Zhou \& Bondy 1993).

In women undergoing controlled ovarian hyperstimulation $(\mathrm{COH})$ and in vitro fertilization (IVF), serum IGF-I levels at the preovulatory stage are substantially higher than those in follicular fluid (Chang et al. 1994, Pellegrini et al. 1995). These observations imply that IGF-I in follicular fluid is probably derived by diffusion from the peripheral circulation and that local production of IGF-I in granulosa cells of the dominant follicle is unlikely. In preovulatory follicular fluid of patients undergoing $\mathrm{COH}$ and IVF, IGF-II levels are approximately 8-fold higher than those of IGF-I (Kubota et al. 1993). Additionally, IGF-II increases the release of estradiol from cultured human granulosa cells in a dose-dependent manner (Kubota et al. 1993). Taken together, development of human granulosa cells may be regulated by IGFs (IGF-II synthesized de novo and IGF-I from the circulation) via IGF receptors, though IGF-I may not be synthesized de novo in the follicle.

Immunohistochemical studies with human ovary have localized IGF-I peptides to the theca-interstitial compartment (Hernandez et al. 1992). IGF-I cannot stimulate de novo steroidogenesis alone because it does not stimulate cholesterol transport into the mitochondria (Magoffin \& Weitsman 1996). In theca-interstitial cells, IGF-I, in combination with $\mathrm{LH}$, increases $\mathrm{LH}$ receptors, augments LH-stimulation of cAMP and enhances androgen biosynthesis (Cara \& Rosenfield 1988, Magoffin \& Erickson 1988, Magoffin et al. 1990, Bergh et al. 1993, Huang et al. 1994, Nahum et al. 1995). In addition, the synergistic action of LH and IGF-I on the substantial production of androgen has also been observed in cultured human thecal monolayers (Hillier et al. 1991). Furthermore, using in situ hybridization, IGF-I gene expression is localized to theca cells of atretic and small developing follicles $(3-5 \mathrm{~mm})$ in human ovary (El Roeiy et al. 1994). This implies that IGF-I of thecal origin may facilitate LH action on androgen production. In contrast, IGF-I in the granulosa cells is capable of augmenting FSH-mediated estrogen synthesis (Adashi et al. 1985a, Christman et al. 1991); and after luteinization, in synergy with LH, stimulating progesterone synthesis (Adashi et al. 1985b, Davoren et al. 1985).

At the preovulatory stage, IGFBP-1 levels in follicular fluid are substantially higher than those in serum (Chang et al. 1994). As with the preovulatory peak of serum estradiol, which reflects the production of estradiol by granulosa cells of dominant follicles, serum levels of IGFBP-1 are significantly increased at the preovulatory stage under both non-fasting and fasting conditions (Wang et al. 1995, Juul et al. 1997). This is consistent with previous results that IGFBP-1 levels in both serum (Martikainen et al. 1991) and follicular fluid (Thierry van dessel et al. 1996) are substantially elevated at the preovulatory stage in controlled hyperstimulation cycles. In addition, these findings are further supported by results from studies using in situ hybridization that abundant expression of IGFBP-1 mRNA is only present in the granulosa cells of dominant follicles (El Roeiy et al. 1994). However, there is still a controversy since other investigators fail to find any alterations in serum IGFBP-1 during the normal menstrual cycle (Thierry van dessel et al. 1996, Helle et al. 1998). It is possible that production of IGFBP-1 by ovarian granulosa cells may or may not be reflected by the circulating IGFBP-1 levels. IGFBP-1 in the ovary during the follicular phase is believed to inhibit IGF-I-induced androgen production by theca cells and in turn inhibit/prevent follicular atresia and anovulation by acting through enhancement of estradiol formation in granulosa cells (a shift from androgen-dominant to estrogen-dominant follicles) (Nobels \& Dewailly 1992). These observations indicate that local production of IGFBP-1 (of granulosa cell origin) in dominant follicles at the preovulatory stage is substantial and that it may be important in the regulation of follicular growth and maturation by modulating the actions of IGF-I (from systemic circulation) on the production of androgen in theca cells.

In normal human ovaries, IGFBP-4 can be immunolocalized to the granulosa and theca cells of atretic follicles, but is negligible in primordial, preantral and antral follicles (Peng et al. 1996). The follicular fluid of atretic/androgendominant follicles contains high levels of IGFBP-2 and IGFBP-4, which are known to inhibit the action of IGF-II (Cataldo \& Giudice 1992a, San Roman \& Magoffin 1993, Giudice et al. 1995). In contrast, an increase in the amount of lower molecular mass forms of IGFBP-2, -3 and -4 (23, 29 and $16 \cdot 5 \mathrm{kDa}$ respectively) in dominant follicles suggests an increased activity of proteases for IGFBPs (Cwyfan Hughes et al. 1997). Moreover, IGFBP-4 protease activity is also observed in the follicular fluid of developing but not atretic follicles (Chandrasekher et al. 1995, Iwashita et al. 1996). The protease activity may specifically cleave IGFBPs into smaller fragments that have a markedly reduced affinity for IGFs and in turn potentiate IGF actions (Conover et al. 1993, Mason et al. 1996). In vitro studies have shown that IGFBP-4 proteolytic activity is increased when granulosa cells are incubated with IGFs, estradiol or FSH, but not with testosterone. In addition, IGFBP-4 inhibits IGF-I-induced estradiol release by granulosa cells while proteolyzed IGFBP-4 does not (Iwashita et al. 1996). Thus, proteolysis of IGFBPs in 


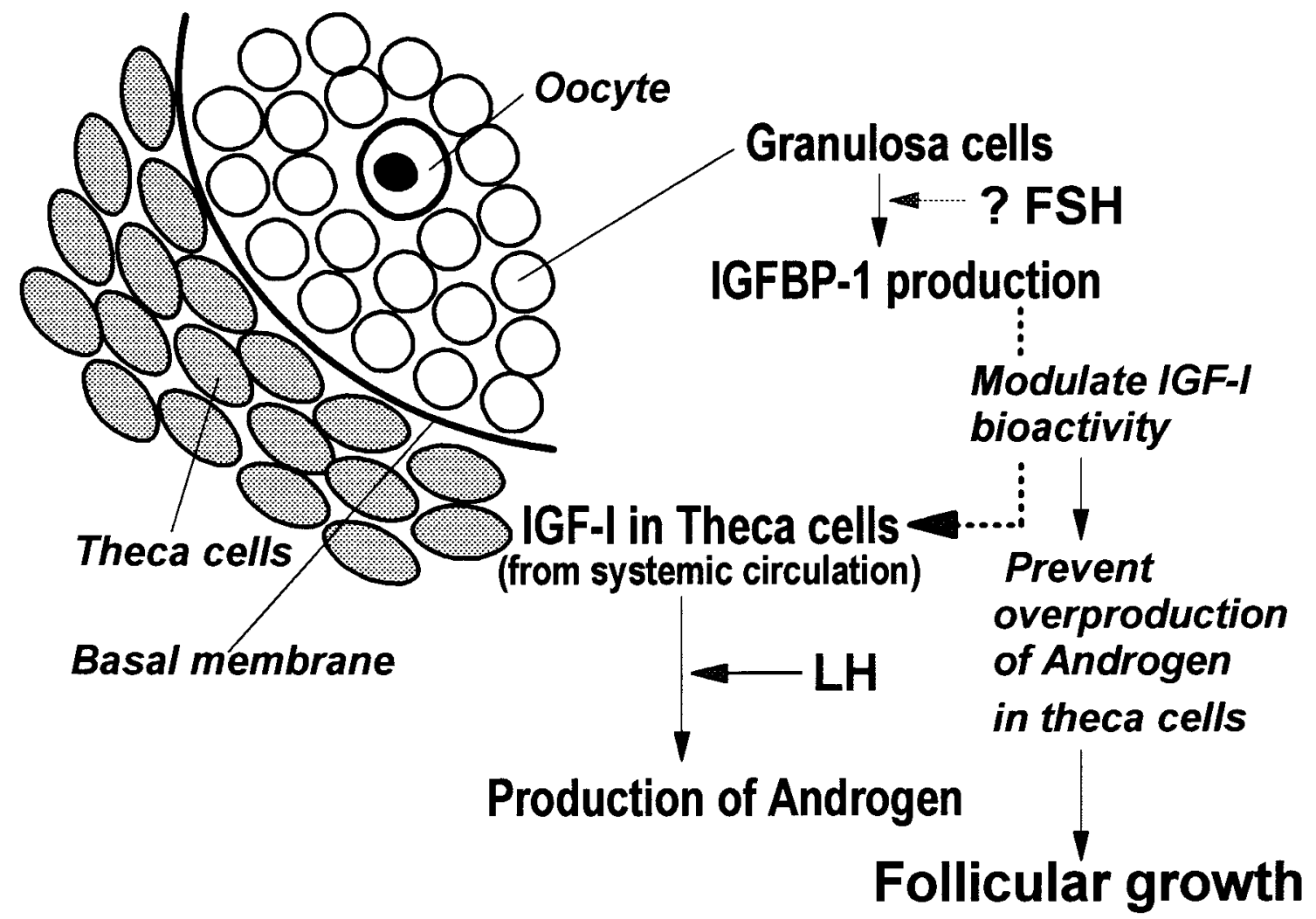

Figure 1 Androgen production in 'human' theca cells is controlled by IGF-I in synergy with LH; IGFBP-1 of granulosa cell origin prevents overproduction of androgens by theca cells through inhibition of IGF actions.

follicles may be an important mechanism by which bioactive IGFs are made available to granulosa cells.

Thus, there appear to be two mechanisms by which IGFs and IGFBPs are involved in the control of follicular growth and development. Androgen production in theca cells is controlled by IGF-I in synergy with LH; IGFBP-1 of granulosa cell origin may play an important role in modulating IGF-I bioactivity in theca cells and thereby prevent overproduction of androgens (Fig. 1). On the other hand, FSH-induced estradiol production in granulosa cells is mediated by IGF-II synthesized in situ. Concomitantly, less production of certain IGFBPs (e.g. IGFBP-2, -4 and -5) and more production of their specific proteases accentuate the actions of IGF-II. Based on currently available data, the following hypothesis is proposed. In the granulosa cells of the dominant follicle, FSH might stimulate expression of the IGF-II gene and the IGFBP protease genes, and at the same time, expression of the IGFBP genes (e.g. IGFBP-2, -4 and -5 ) might be inhibited. In addition, the elevated IGFBP proteases cleave IGFBP-2, -4 and -5 into smaller inactive fragments. The resultant activation of IGF might stimulate FSHinduced estradiol production and in turn potentiate proliferation of granulosa cells (Fig. 2). In growing and developing follicles, events in both theca and granulosa cells progress simultaneously and interact with each other. Failure of progression in either the theca or the granulosa may result in follicular atresia.

\section{Luteal regression}

Recent studies have shown that IGFBP-3 is abundant in the follicular fluid of growing follicles (Sarvas et al. 1994) and progressively decreased in dominant follicles as they grow to preovulatory size (San Roman \& Magoffin 1993). In cultured human luteinizing granulosa cells, synthesis of IGFBP-3 is stimulated by GH and inhibited by FSH. Conversely, IGFBP-3 is also able to inhibit the stimulatory effect of FSH on granulosa cells. As the action of IGFBP-3 is exerted by binding of the IGF peptides, the inhibitory effect on FSH is believed to occur through blocking of the binding between IGF-I and membrane receptors, rather than attenuation of IGF-I potency (Barreca et al. 1996). In the luteal phase of the ovarian cycle, prostaglandin $\mathrm{F}_{2 \alpha}$ $\left(\mathrm{PGF}_{2 \alpha}\right)$ also stimulates release of IGFBP-3 from human granulosa-luteal cells and inhibits IGF-I-induced progesterone production. This $\mathrm{PGF}_{2 \alpha}$-induced stimulation of IGFBP-3 production may be one of the mechanisms 


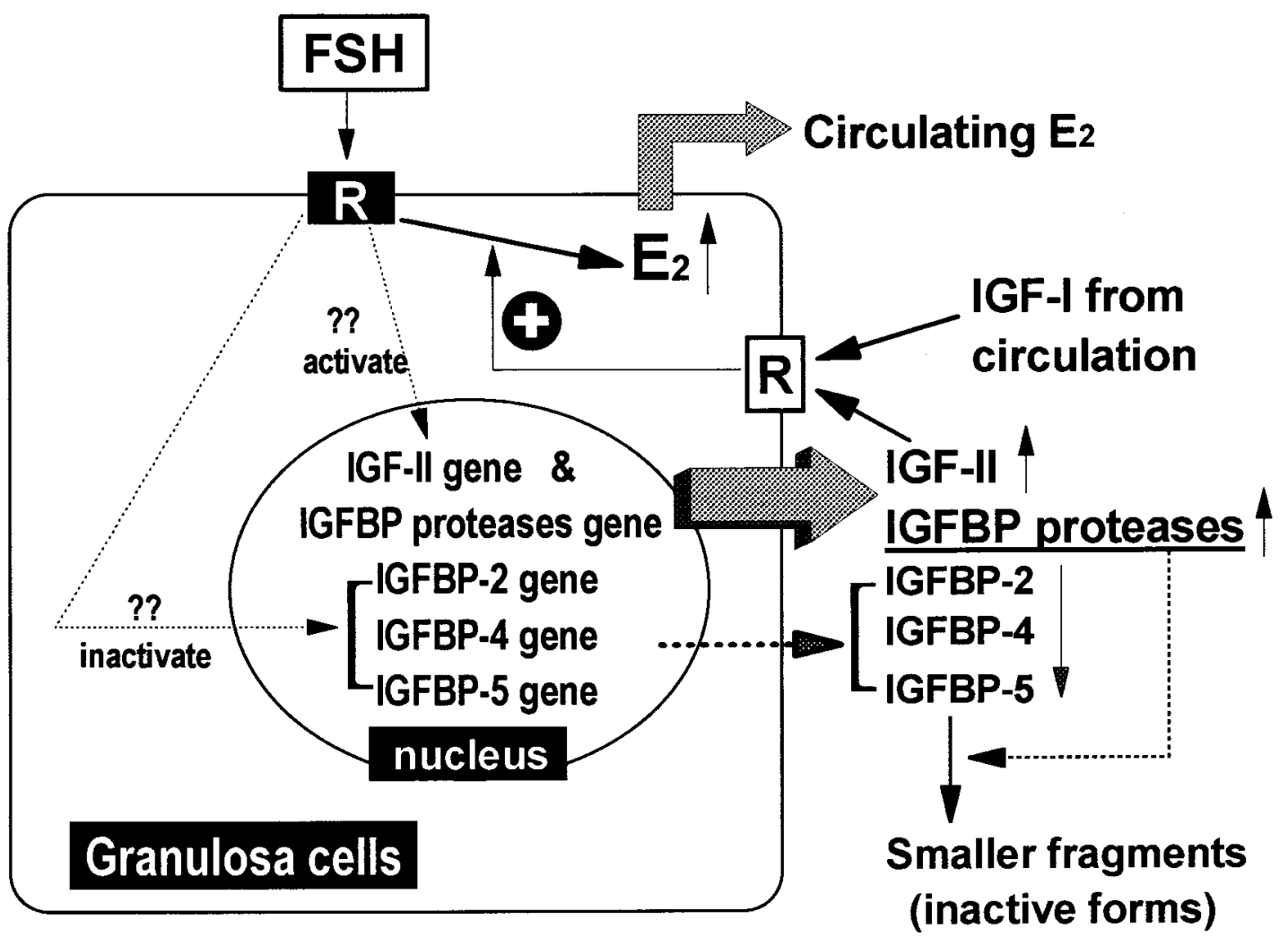

Figure 2 Hypothetically, in the granulosa cells of the 'human' dominant follicle, FSH might activate gene expression of IGF-II and IGFBP proteases and inhibit expression of IGFBP-2, -4 and -5 . In addition, the elevated IGFBP proteases cleave IGFBP-2, -4 and -5 into smaller inactive fragments. The net result is increased IGF-II activity in granulosa cells. In synergy with FSH, both IGF-I (from the circulation) and IGF-II (synthesized de novo) stimulate production of estradiol $\left(E_{2}\right)$ through IGF receptors and in turn induce proliferation of granulosa cells and follicular growth. White R, FSH receptor; black R, IGF-I and IGF-II receptor.

whereby $\mathrm{PGF}_{2 \alpha}$ exerts its luteolytic effect via the IGF system (Sarvas et al. 1994). Thus, IGFs and IGFBPs are involved in progesterone synthesis and spontaneous regression of the corpus luteum.

\section{Polycystic ovarian syndrome (PCOS)}

IGFBPs are thought to play an important role in regulating ovarian function by modifying the effects of IGFs or by directly affecting ovarian steroidogenesis. This is likely to be important in hyperinsulinemic insulin-resistant conditions, such as PCOS.

In both normal human ovaries and polycystic ovaries, granulosa cells may or may not secrete IGFBP-1 in response to FSH (Mason et al. 1993). In contrast, the addition of IGF-I to granulosa cells incubated with testosterone or testosterone plus FSH causes complete inhibition of IGFBP-1 production (Mason et al. 1993). In women with both polycystic-appearing ovaries and PCOS, serum levels of IGFBP-1 are significantly lower than in those with normal-appearing ovaries (Carmina et al. 1997). In addition, IGFBP-1, analyzed by Western ligand blotting, is not detected in follicular fluid in PCOS (Cataldo \& Giudice 1992b). Normally, the ovarian stroma has specific binding sites both for insulin and for IGF-I (Nagamani \& Stuart 1990). Additionally, both insulin and IGF-I potentiate $\mathrm{LH}$-induced testosterone and androstenedione secretion in cultured human theca cells (Bergh et al. 1993). In women with PCOS, hyperinsulinemia with insulin resistance and stimulation of ovarian androgen synthesis by insulin mediated through the type I IGF receptors are commonly observed (Nagamani \& Stuart 1990). In situ hybridization studies have shown that abundant expression of IGFBP-1 mRNA is only found in the granulosa cells of dominant follicles and not in those of atretic follicles (El Roeiy et al. 1994). Additionally, in vitro studies have shown that both insulin and IGF-I inhibit IGFBP-1 production by cultured human luteinizing granulosa cells. Insulin exerts its inhibitory effect on IGFBP-1 production via insulin receptors, while IGF-I appears to exert its effect via IGF receptors (Poretsky et al. 1996). These findings indicate that a decrease in IGFBP-1 produced by 


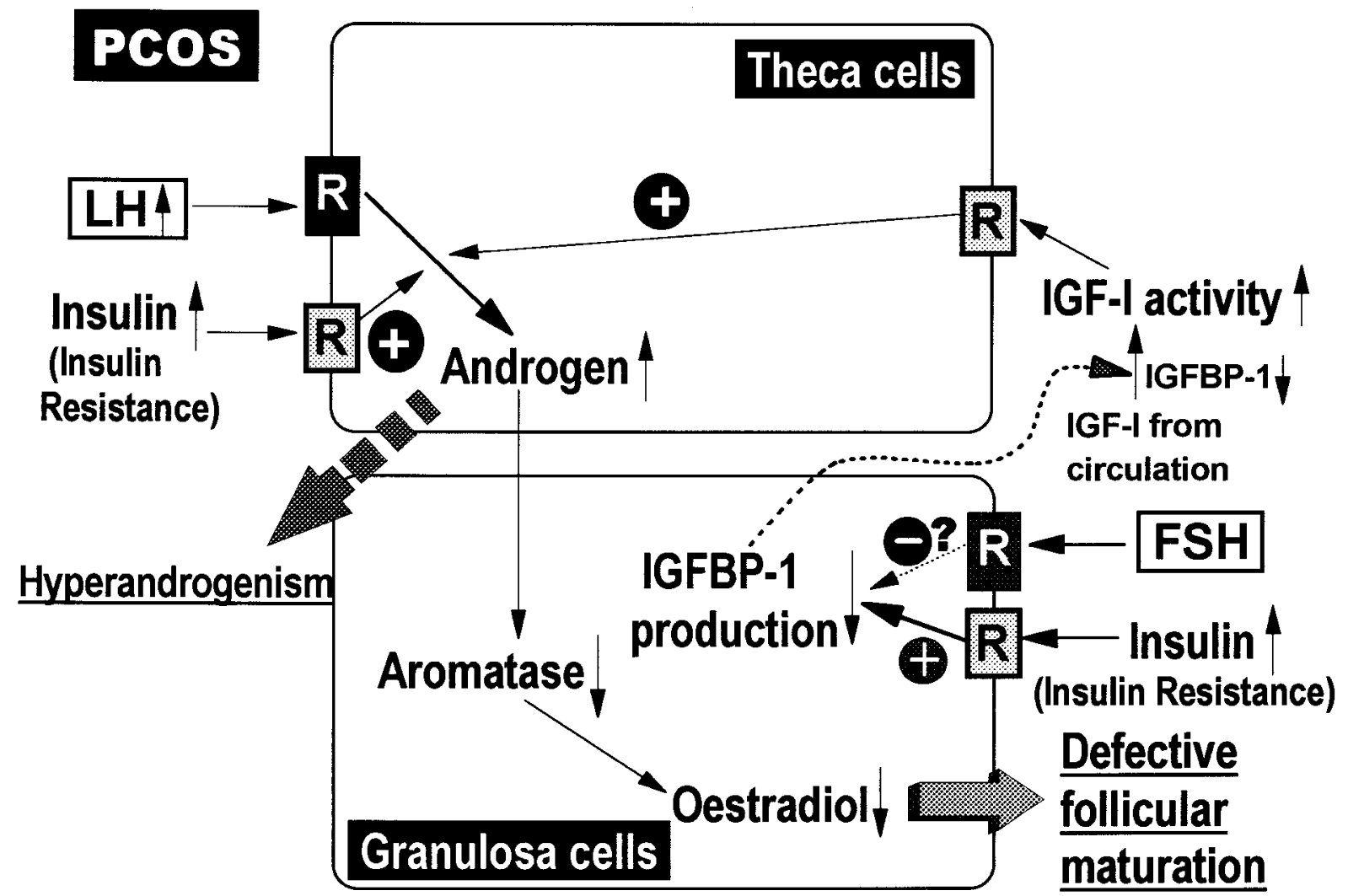

Figure 3 The involvement of IGFBP-1 in the pathogenesis of PCOS. Deficient production of IGFBP-1 in granulosa cells results from hyperinsulinemia (insulin resistance) and/or inadequate FSH and therefore intensifies IGF-I activity in theca cells. The high circulating insulin (hyperinsulinemia) may enhance LH-mediated androgen production in theca cells by acting through type I IGF receptors. The resultant overproduction of androgens (as a consequence of elevated insulin, LH and IGF-I activity at the level of theca cells) in turn inhibits aromatase activity in granulosa cells. Reduced estradiol leads to decreased proliferation of granulosa cells and thus defective follicular maturation.

granulosa cells may insufficiently antagonize IGF-I bioactivity in theca-stromal cells, resulting in overproduction of androgens and in turn defective follicular maturation and anovulation (Fig. 3). This is further supported by the clinical observation that the decrease in serum IGF-I concentrations and increase in serum IGFBP-1 induced by combined oral contraceptives appears to decrease ovarian androgen production in women with polycystic ovarian disease (Suikkari et al. 1991), resulting in an increased follicular response to ovarian stimulation regimens.

PCOS often develops during puberty. At the onset of puberty, increased pulsatile $\mathrm{GH}$ secretion results in insulin resistance and compensatory hyperinsulinemia (Bloch et al. 1987). The increased serum insulin levels further decrease hepatic synthesis of IGFBP-1 (Weaver et al. 1990) and in turn enhance the bioactivity of IGF-I. Based on the similar changes of IGF-I and IGFBP-1 in PCOS and puberty, it is plausible to speculate that there is an association between PCOS and puberty (Nobels \& Dewailly 1992).

In human granulosa cells, IGFBP-1 and estradiol are differentially regulated by IGF-I. In the presence of FSH,
IGF-I stimulates granulosa cells to produce estradiol in a dose-dependent manner (Mason et al. 1993). The IGF-Iinduced estradiol production is also modulated by other species of IGFBPs. The abundant expression of IGFBP-4 in granulosa and theca cells of preantral and antral follicles of PCOS ovaries may lead to a decrease in the bioavailability of IGF-I in those follicles (Peng et al. 1996). The decrease in IGF-I-mediated stimulation of gonadotropin actions on granulosa and theca cells in preantral and antral follicles may in turn impair the induction of aromatase activity, causing an androgenic microenvironment which is characteristic of atretic follicles and PCOS follicles (Peng et al. 1996).

IGF-I and IGF-II significantly increase androgen production from the adrenal gland via activation of type I IGF receptors on adrenal cortical cells (Mesiano et al. 1997). During steroidogenesis, the cytochrome $\mathrm{P} 450 \mathrm{c} 17 \alpha$ is expressed as both $17 \alpha$-hydroxylase and 17,20-desmolase, and catalyzes androgen production. In addition, IGF-I can stimulate both LH-dependent P450c17 $\alpha$ activity in ovaries and adrenocorticotropin-dependent activity in 
adrenals (Penhoat et al. 1989). Consequently, both the accentuated IGF-I bioactivity and the activation of type I IGF receptors in the adrenal gland may play a pivotal role in androgen production in PCOS.

\section{IGFs and IGFBPs in the endometrium}

\section{Regulation of proliferation and differentiation in the endometrium}

In the human endometrium, mRNAs for IGF-I, IGF-II and IGFBPs 1-6 are expressed during the menstrual cycle. Specifically, IGF-I mRNA is substantially higher during the proliferative than the secretory phase, whereas the converse is true for IGF-II (Zhou et al. 1994, Gao et al. 1995). Furthermore, IGFBP-2, $-4,-5$ and -6 mRNAs demonstrate a diffuse stromal pattern of expression, whereas IGFBP-1 and -3 are more concentrated in selected subpopulations of endometrial cells (Rutanen et al. 1991, 1993, Zhou et al. 1994). IGFBP-2 and IGFBP-3 mRNAs are significantly increased in the late secretory phase of the endometrium (Giudice et al. 1991). Moreover, IGFBP-3 mRNA is primarily concentrated in endometrial capillaries, largely due to the intensive vascularization of endometrial glands during the secretory phase (Zhou et al. 1994). IGFBP-4 and IGFBP-5 mRNAs remain unchanged during the menstrual cycle (Rutanen et al. 1993). IGFBP-1 mRNA is not detected in proliferative endometrium but is present in the stromal cells of the secretory endometrium (Julkunen et al. 1990, Rutanen et al. 1991, Zhou et al. 1994).

IGF-I mRNA is present in early proliferative phase endometrium and is most abundant in the late proliferative phase (Boehm et al. 1990, Zhou et al. 1994). The cyclic changes of IGF-I mRNA in the proliferative phase of the endometrium are coincident with serum estradiol concentrations. Giudice and her coworkers have also reported that endometrial growth in the proliferative phase is accelerated by ovarian estradiol via local production of IGF-I, which in turn stimulates cell proliferation (Giudice et al. 1993). IGFs bind to both cell membrane receptors and soluble IGFBP-1 with similar affinity. Thus, IGFBP-1 inhibits binding of IGF-I to its endometrial IGF receptors and reduces the availability of IGF-I at the cellular level (Rutanen et al. 1988). After ovulation, progesterone is prominent and stimulates the endometrial stromal cells to secrete IGFBP-1, which in turn modulates the bioactivity of IGF-I (Rutanen \& Pekonen 1991). In addition, IGFBP-1 mRNA is localized to predecidualized stromal cells in late secretory endometrium and to decidual cells in pregnancy endometrium (Julkunen et al. 1990, Rutanen et al. 1991). The timing and cellular localization of IGFBP-1 in human endometrium suggest that this protein is associated with decidual differentiation of the stromal cells. Furthermore, the IGF receptors on human endometrial stromal cells are downregulated by progesterone and in turn inhibit the growth-promoting actions of IGF-I (Strowitzki et al. 1996). Both effects result in inhibition of endometrial stromal growth and acceleration of cell differentiation during the secretory phase.

In women with a progestin (levonorgestrel)-releasing intrauterine contraceptive device (IUCD), IGFBP-1 is present in abundance in decidualized stromal cells of the endometrium (Pekonen et al. 1992, Suhonen et al. 1996). Furthermore, the decidual reaction and epithelial atrophy induced by intrauterine progestin (levonorgestrel) are associated with expression of IGFBP-1 in decidualized stromal cells (Suhonen et al. 1996). In contrast, there is no difference in circulating IGFBP-1 levels between IUCD (without progestin) users and non-IUCD users (Seleem et al. 1996). Studies using cell cultures have also shown that progesterone (medroxyprogesterone acetate) stimulates IGFBP-1 secretion in cultured endometrial stromal cells (Bell et al. 1991). These findings further confirm that synthesis of endometrial IGFBP-1 is progesterone dependent (Julkunen et al. 1988, Rutanen \& Pekonen 1991). An immunohistochemical study has shown that administration of micronized progesterone $(100 \mathrm{mg}$ /day orally, or $100-200 \mathrm{mg} /$ day vaginally) cannot prevent the proliferative effect of estrogen (Suvanto-Luukkonen et al. 1995). In endometrial samples from women treated with micronized progesterone, no signs of progestin effect are detected by microscopic examination; in addition, immunohistochemical staining of IGFBP-1 is completely negative in endometrial stromal cells (Suvanto-Luukkonen et al. 1995). Thus, it is tempting to speculate that the immunohistochemical detection of IGFBP-1 in endometrial stromal cells may be used to assess the degree of progestin effect in the endometrium during hormone replacement therapy.

In postmenopausal women, abnormal uterine bleeding is frequently observed as a deficient progesterone effect. Microscopically, there is often simple hyperplasia and hypertrophy of the endometrium. In our own studies, using reverse transcription-polymerase chain reaction (RT-PCR), expression of both IGF-II and IGFBP-1 mRNA was not detected in endometrium from postmenopausal women with abnormal uterine bleeding. In contrast, expression of IGF-II mRNA was detected and that of IGFBP-1 mRNA was relatively abundant in the endometrium from postmenopausal women 3-6 months after progesterone (medroxyprogesterone acetate $5 \mathrm{mg} /$ day) treatment in association with estrogen supplementation (Fig. 4). Expression of IGF-I mRNA was observed in the endometrium with or without progesterone treatment. Histologically, simple hyperplasia and hypertrophy of the endometrium was no longer observed after progesterone treatment. These data provide evidence that the protective effects of progesterone on the endometrium might be mediated through the expression of IGFBP-1, which in turn could inhibit the growth-promoting effects of IGF-I. They also suggest that the differentiation of 


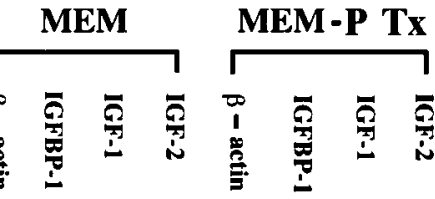

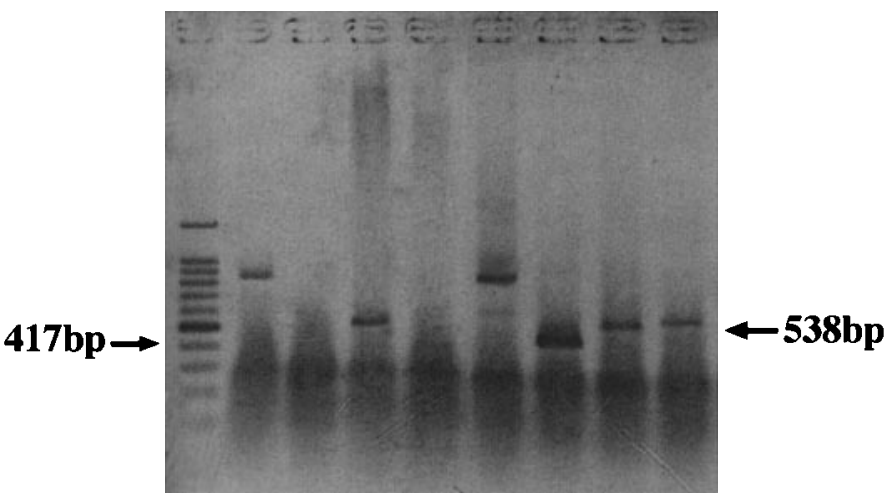

Figure 4 Effects of progesterone on expression of mRNAs for IGF-II and IGFBP-1 in the endometrium. Using RT-PCR, expression of both IGF-II and IGFBP-1 mRNA (corresponding to 538 and 417 bp respectively) was not detected in the endometrium from postmenopausal women with unopposed estrogen stimulation and abnormal uterine bleeding (MEM). After progesterone (medroxyprogesterone acetate $5 \mathrm{mg}$ /day) treatment in association with estrogen supplementation for 3-6 months (MEM-P Tx), expression of IGF-II mRNA was detected and that of IGFBP-1 mRNA was relatively abundant in the endometrium from those postmenopausal women. Reverse transcription was performed using $10 \mu \mathrm{g}$ total RNA from endometrium followed by a 30-cycle PCR. Primers for IGFBP-1 RT-PCR were 5' TACAT CTGGC AGTTG GGGTC TCC 3' (antisense) and 5' TGCAG AGGCA GGGAG CCCTG AAA $3^{\prime}$ (sense), for IGF-I RT-PCR 5' ACATC TCCCA TCTCT CTGGA TTTCC TTTTGC $3^{\prime}$ (antisense) and $5^{\prime}$ CCCTC TACTT GCGTT CTTCA AATGT ACTTCC $3^{\prime}$ (sense), and for IGF-II RT-PCR 5' AGTCG ATGCT GGTGC TTCTC ACCTT CTTGGC 3' (antisense) and 5' TGCGG CAGTT TTGCT CACTT CCGAT TGCTGG 3' (sense).

the endometrium might be mediated by IGF-II under the regulation of progesterone.

Involvement of IGFs/IGFBPs in implantation - interaction between the endometrium and the embryo

The expression of IGF genes in the uterus can be regulated by estrogen secreted by implanting mammalian embryos of several species, suggesting that IGFs may play a role in implantation (Ko et al. 1994). In the presence of progesterone and epidermal growth factor, both IGF-I and IGF-II in vitro induce production of IGFBP-1 and prolactin by the human endometrium in a dose-dependent biphasic manner; stimulation of production by low doses of IGFs and inhibition by higher doses (Irwin et al. 1994). At the peri-implantation stage, local production of IGFBP-1 by the endometrium in the presence of progesterone appears to stimulate the differentiation and secretory function of the endometrium (Rutanen \& Pekonen 1991). After implantation, IGFBP-1 can be detected immuno- histochemically in both the decidualized endometrium in intrauterine pregnancy and decidualized stromal cells at the implantation site in ovarian pregnancy (Rutanen \& Pekonen 1991). IGFBP-1 of decidual origin is believed to inhibit the bioactivity of IGF-I (Pekonen et al. 1988, Ritvos et al. 1988) and may protect the endometrium from invasion by trophoblast. This is further supported by the fact that IGF-induced mitogenesis is inversely correlated with endogenous IGFBP-1 levels in decidualized stromal cultures (Irwin et al. 1994). Furthermore, supplementation with vaginal micronized progesterone during the luteal phase appears to directly stimulate endometrial production of IGFBP-1 (Wang \& Soong 1996). The accentuated local production of endometrial IGFBP-1 may in turn inhibit embryo implantation and decrease the pregnancy rate (Wang \& Soong 1996).

There is clear evidence that IGF-I and IGF-II stimulate both cell proliferation and differentiation of preimplantation embryos (Smith et al. 1993, Shi et al. 1994). Embryos co-cultured with various epithelial monolayers show improved development (Lai et al. 1996). 
In such systems, IGFBP-1, $-2,-3,-4$ and -5 are produced by the monolayer helper cells (human endometrial and oviductal cells). Of these binding proteins, IGFBP-3 is the most prominent in co-cultured human endometrial monolayers and may play a role in embryo development either by regulating IGF actions or by directly enhancing embryo development (Lai et al. 1996).

Using immunocytochemical techniques with a monoclonal antibody to proliferating cell nuclear antigen, an effect of IGF-I on the proliferative activity of trophoblasts is observed during early pregnancy (4-12 weeks of gestation). In vitro culture of trophoblasts of early pregnancy, secretion of human chorionic gonadotropin and human placental lactogen by trophoblasts is increased by addition of IGF-I, indicating the effect of IGF-I on the differentiated function of trophoblasts (Maruo et al. 1995). These findings suggest that IGF-I acts as an autocrine/ paracrine factor in regulating early placental growth and function.

In a normal pregnancy, maternal serum IGFBP-1 of decidual origin increases rapidly during the first trimester and reaches a peak at 12 to 14 weeks of gestation; thereafter it remains high until term (Wang et al. 1991). Elevated serum IGFBP-1 levels in the third trimester of gestation have been reported in pregnant women complicated by pre-eclampsia (Than et al. 1984, Iino et al. 1986, Howell et al. 1989). Additionally, in pre-eclampsia concomitant with idiopathic intrauterine growth retardation (IUGR), significantly elevated serum levels of IGFBP-1 (Wang et al. 1996, Giudice et al. 1997) and decreased circulating IGF-I concentrations (Giudice et al. 1997) are found in both the mother and the fetus. Similar observations have also been made in both the maternal and fetal circulation in pregnancies complicated by growth retardation (Crystal \& Giudice 1991, Holmes et al. 1997, Ostlund et al. 1997). Pathologically, inadequacy or failure of intravascular trophoblastic infiltration into intramyometrial segments of the spiral arteries between 12 and 14 weeks of gestation is a specific histological feature of both IUGR and pre-eclampsia (Robertson 1976, Meekins et al. 1994, De Groot et al. 1996). There is evidence that IGFBP-1 inhibits cytotrophoblast invasion into decidualized stromal multilayers through binding to cytotrophoblast $\alpha 5 \beta 1$ integrin (Irwin et al. 1996) since IGFBP-1 contains an Arg-Gly-Asp integrin recognition sequence (Jones et al. 1993b). In addition, an abundance of IGFBP-1 is found at the maternal-fetal interface in severely preeclamptic pregnancies, suggesting that IGFBP-1 may participate in the pathogenesis of the shallow or inadequate placental invasion observed in this disorder (Giudice et al. 1997). Functionally, the failure of invasion leads to inadequate circulation and oxygenation of trophoblastic tissue (Khong et al. 1986, De Groot \& Taylor 1993). Thus, low circulating IGF-I and elevated IGFBP-1 levels may contribute to restricted placental and therefore fetal growth. These findings reflect the association between elevated IGFBP-1 and IUGR with or without preeclampsia, and further indicate that endometrial/decidual IGFBP-1 can play an important role in implantation and placentation.

\section{Conclusions}

There is now considerable evidence that IGFs and IGFBPs play a major autocrine and paracrine role in regulation of follicular development and endometrial function. Various molecular forms of IGFBPs act as modulators of the actions of IGFs on reproductive function acting in synergy with pituitary gonadotropins and ovarian steroid hormones. In addition, local production of specific proteases for IGFBPs further mediates the bioactivity of IGFBPs and in turn modulates IGF actions. At various sites in the female reproductive system, small changes (overproduction or deficiency) of IGFBPs may result in pathological conditions such as anovulation and hyperandrogenism, inadequate differentiation of the endometrium, failure of implantation and inadequate placentation.

\section{Acknowledgements}

This work was in part supported by a grant from the National Science Council, Taipei, Taiwan, Republic of China (NSC85-2331-B-182-075).

\section{References}

Adashi EY, Resnick CE, Brodie AMH, Svoboda ME \& Van Wky JJ 1985 a Somatomedin-C-mediated potentiation of follicle-stimulating hormone-induced aromatase activity of cultured rat granulosa cells. Endocrinology 117 2313-2320.

Adashi EY, Resnick CE, Svoboda ME \& Van Wky JJ $1985 b$ Somatomedin-C synergizes with follicle-stimulating hormone in the acquisition of progesterone biosynthetic capacity by cultured rat granulosa cells. Endocrinology 116 2135-2142.

Bar RS, Booth BA, Bowes M \& Drake BL 1989 Insulin-like growth factor-binding proteins from vascular endothelial cells: purification, characterization, and intrinsic biological activities. Endocrinology 125 1910-1920.

Barreca A, Artini PG, Cesarone A, Arvigo M, D’Ambrogio G, Genazzani AR, Giordano G \& Minuto F 1996 Interrelationships between follicle stimulating hormone and the growth hormoneinsulin-like growth factor-IGF-binding proteins axes in human granulosa cells in culture. Journal of Endocrinological Investigation 19 35-42.

Bell SC, Jackson JA, Ashmore J, Zhu HH \& Tseng L 1991 Regulation of insulin-like growth factor binding protein-1 synthesis and secretion by progestin and relaxin in long term cultures of human endometrial stromal cells. Journal of Clinical Endocrinology and Metabolism 72 1014-1024.

Bergh C, Carlsson B, Olsson JH, Selleskog U \& Hillensjo T 1993 Regulation of androgen production in cultured human thecal cells by insulin-like growth factor I and insulin. Fertility and Sterility $\mathbf{5 9}$ 323-331.

Binoux M, Roghani M, Hossenlopp P, Hardouin S \& Gourmelen M 1991 Molecular forms of human IGF-binding proteins: physiological implications. Acta Endocrinologica 124 41-47. 
Bloch CA, Clemons P \& Sperling MA 1987 Puberty decreases insulin sensitivity. Journal of Pediatrics 110 481-487.

Boehm KD, Daimon M, Gorodeski IG, Sheean LA, Utian WH \& Ilan J 1990 Expression of the insulin-like and platelet-derived growth factor genes in human uterine tissues. Molecular Reproduction and Development 27 93-101.

Brown AL, Graham DE, Nissley SP, Hill DJ, Strain AJ \& Rechler MM 1986 Developmental regulation of insulin-like growth factor-II mRNA in different rat tissues. Journal of Biological Chemistry 261 13144-13151.

Busby WH, Klapper DG \& Clemmons DR 1988 Purification of a 31 000-dalton insulin-like growth factor-binding protein from human amniotic fluid. Isolation of two forms with different biological actions. Journal of Biological Chemistry 263 14203-14210.

Cara JF \& Rosenfield RL 1988 Insulin-like growth factor I and insulin potentiate luteinizing hormone-induced androgen synthesis by rat ovarian thecal-interstitial cells. Endocrinology 123 733-739.

Carlsson B, Carlsson L \& Billing H 1989 Estrous cycle-dependent co-variation of insulin-like growth factor I (IGF-I) messenger ribonucleic acid and protein in the rat ovary. Molecular and Cellular Endocrinology 64 271-275.

Carmina E, Wong L, Chang L, Paulson RJ, Sauer MV, Stanczyk FZ \& Lobo RA 1997 Endocrine abnormalities in ovulatory women with polycystic ovaries on ultrasound. Human Reproduction 12 905-909.

Cataldo NA 1997 Insulin-like growth factor binding proteins: do they play a role in polycystic ovary syndrome? Seminars in Reproductive Endocrinology 15 123-136.

Cataldo NA \& Giudice LC 1992a Insulin-like growth factor binding protein profiles in human ovarian follicular fluid correlate with follicular functional status. Journal of Clinical Endocrinology and Metabolism 74 821-829.

Cataldo NA \& Giudice LC $1992 b$ Follicular fluid insulin-like growth factor binding protein profiles in polycystic ovary syndrome. Journal of Clinical Endocrinology and Metabolism 74 695-697.

Chandrasekher YA, Van Dessel HJHM, Fauser BCJM \& Giudice LC 1995 Estrogen- but not androgen-dominant human ovarian follicular fluid contains an insulin-like growth factor binding protein-4 protease. Journal of Clinical Endocrinology and Metabolism 80 2734-2739.

Chang SY, Hiesh KC, Wang HS \& Soong YK 1994 Follicular fluid levels of insulin-like growth factor-I, insulin-like growth factor binding protein-1 and ovarian steroids collected during ovum pick-up. Fertility and Sterility 62 1162-1167.

Christman GM, Randolph JF Jr, Peegel H \& Menon KMJ 1991 Differential responsiveness of luteinized human granulosa cells to gonadotropins and insulin-like growth factor I for induction of aromatase activity. Fertility and Sterility 55 1099-1105.

Clairmont KB \& Czech MP 1989 Chicken and Xenopus mannose6-phosphate receptors fail to bind insulin-like growth factor-II. Journal of Biological Chemistry 264 16390-16392.

Conover CA, Kiefer MC \& Zapf J 1993 Posttranslational regulation of insulin-like growth factor binding protein-4 in normal and transformed human fibroblasts. Insulin-like growth factor dependence and biological studies. Journal of Clinical Investigation 91 1129-1137.

Crystal RA \& Giudice LC 1991 Insulin-like growth factor binding protein (IGFBP) profiles in human fetal cord sera: ontogeny during gestation and differences in newborns with intrauterine growth retardation (IUGR) and large for gestational age (LGA) newborns. In Modern Concepts of Insulin-Like Growth Factors, pp 395-408. Ed EM Spencer. New York: Elsevier.

Cwyfan Hughes S, Mason HD, Franks S \& Holly JM 1997 Modulation of the insulin-like growth factor-binding proteins by follicle size in the human ovary. Journal of Endocrinology 154 35-43.

Davoren JB, Hsueh AJW \& Li CH 1985 Somatomedin C augments FSH-induced differentiation of cultured rat granulosa cells. American Journal of Physiology 249 E26-E33.
DeChiara T, Efstratiadis A \& Robertson EA 1990 Growth-deficient phenotype in heterozygous mice carrying an insulin-like growth factor II gene disruption by targeting. Nature 345 78-80.

De Groot CJM \& Taylor RN 1993 New insights into the etiology of preeclampsia. Annals of Medicine 25 243-249.

De Groot CJ, O’Brien TJ \& Taylor RN 1996 Biochemical evidence of impaired trophoblastic invasion of decidual stroma in women destined to have preeclampsia. American Journal of Obstetrics and Gynecology 175 24-29.

El-Roeiy A, Chen X, Roberts VJ, LeRoith D, Roberts CT Jr \& Yen SS 1993 Expression of insulin-like growth factor-I (IGF-I) and IGF-II and the IGF-I, IGF-II, and insulin receptor genes and localization of the gene products in the human ovary. Journal of Clinical Endocrinology and Metabolism 77 1411-1418.

El-Roeiy A, Chen X, Roberts VJ, Shimasaki S, Ling N, LeRoith D, Roberts CT Jr \& Yen SS 1994 Expression of the genes encoding the insulin-like growth factors (IGF-I and -II), the IGF and insulin receptors, and IGF-binding proteins-1-6 and the localization of their gene products in normal and polycystic ovary syndrome ovaries. Journal of Clinical Endocrinology and Metabolism $\mathbf{7 8}$ 1488-1496.

Erickson GF, Nakatani A, Liu X-J, Shimasaki S \& Ling N 1994 Role of insulin-like growth factors (IGF) and IGF-binding proteins in folliculogenesis. In Molecular Biology of the Female Reproductive System, pp 101-127. Ed JK Findlay. San Diego: Academic Press.

Florini JR, Magri KA, Ewton DZ, James PL, Grindstaff K \& Rotwein PS 1991 'Spontaneous' differentiation of skeletal myoblasts is dependent upon autocrine secretion of insulin-like growth factor-II. Journal of Biological Chemistry 266 15917-15923.

Froesch ER \& Zapf J 1985 Insulin-like growth factors and insulin: comparative aspects. Diabetologia 28 485-493.

Gao JG, Zhu HH, Fan J, Mazella J \& Tseng L 1995 Progestin and antiprogestin differentially regulate the expression of insulin-like growth factors (IGF-I and IGF-II) messenger ribonucleic acid in human endometrial stromal cells. Biology of Reproduction $\mathbf{5 3}$ 355-360.

Ghahary A \& Murphy LJ 1989 Regulation of uterine insulin-like growth factor receptors by estrogen and variation throughout the estrous cycle. Endocrinology 125 597-604.

Giudice LC, Milkowski DA, Lamson G, Rosenfeld RG \& Irwin JC 1991 Insulin-like growth factor-binding proteins in human endometrium: steroid-dependent message ribonucleic acid expression and protein synthesis. Journal of Clinical Endocrinology and Metabolism 72 779-787.

Giudice LC, Dsupin BA, Jin IH, Vu TH \& Hoffman AR 1993 Differential expression of messenger ribonucleic acids encoding insulin-like growth factors and their receptors in human uterine endometrium and decidua. Journal of Clinical Endocrinology and Metabolism 76 1115-1122.

Giudice LC, van Dessel HJ, Cataldo NA, Chandraswkher YA, Yap OW \& Fauser BC 1995 Circulating and ovarian IGF binding proteins: potential roles in normo-ovulatory cycles and in polycystic ovarian syndrome. Progress in Growth Factor Research 6 397-408.

Giudice LC, Martina NA, Crystal RA, Tazuke S \& Druzin M 1997 Insulin-like growth factor binding protein-1 at the maternal-fetal interface and insulin-like growth factor-I, insulin-like growth factor-II, and insulin-like growth factor binding protein-1 in the circulation of women with severe preeclampsia. American Journal of Obstetrics and Gynecology 176 751-757.

Guler HP, Zapf J \& Froesch ER 1987 Short-term metabolic effects of recombinant insulin-like growth factor in healthy adults. New England Journal of Medicine 317 137-140.

Guler HP, Zapf J, Schmid C \& Froesch ER 1989 Insulin-like growth factors I and II in healthy man. Estimations of half-lives and production rates. Acta Endocrinologica 121 753-758.

Han VK, Bassett N, Walton J \& Challis JR 1996 The expression of insulin-like growth factor (IGF) and IGF-binding protein (IGFBP) 
genes in the human placenta and membranes: evidence for IGF-IGFBP interactions at the feto-maternal interface. Journal of Clinical Endocrinology and Metabolism 81 2680-2693.

Helle SI, Anker GB, Meadows KA, Holly JMP \& Lonning PE 1998 Alterations in the insulin-like growth factor system during the menstrual cycle in normal women. Maturitas 28 259-265.

Hernandez ER, Roberts CT Jr, LeRoith D \& Adashi EY 1989 Rat ovarian insulin-like growth factor I (IGF-I) gene expression is granulosa cell-selective: $5^{\prime}$-untranslated mRNA variant representation and hormonal regulation. Endocrinology 125 572-575.

Hernandez ER, Roberts CT Jr, Hurwitz A, LeRoith D \& Adashi EY 1990 Rat ovarian insulin-like growth factor II gene expression is theca-interstitial cell-exclusive: hormonal regulation and receptor distribution. Endocrinology 127 3249-3251.

Hernandez ER, Hurwitz A \& Vera A 1992 Expression of the genes encoding the insulin-like growth factors and their receptors in the human ovary. Journal of Clinical Endocrinology and Metabolism $\mathbf{7 4}$ 419-426.

Hillier SG, Yong EL, Illingworth PJ, Baird DT, Schwall RH \& Mason AJ 1991 Effect of recombinant inhibin on androgen synthesis in cultured human thecal cells. Molecular and Cellular Endocrinology 75 R1-R6.

Holly JMP \& Wass JAH 1989 Insulin-like growth factors: autocrine, paracrine or endocrine? New prospective of the somatomedin hypothesis in the light of recent developments. Journal of Endocrinology 122 611-618.

Holmes R, Montemagno R, Jones J, Preece M, Rodeck C \& Soothill P 1997 Fetal and maternal plasma insulin-like growth factors and binding proteins in pregnancies with appropriate or retarded fetal growth. Early Human Development 49 7-17.

Howell RJS, Economides D, Teisner B, Farkas AG \& Chard T 1989 Placental protein 12 and 14 in pre-eclampsia. Acta Obstetrica et Gynecologica Scandinavica 68 237-240.

Huang ZH, Clayton PE, Brady G \& Morris ID 1994 Insulin-like growth factor-I gene expression in human granulosa-lutein cells. Journal of Molecular Endocrinology 12 283-291.

Iino K, Sjoberg J \& Seppala M 1986 Elevated circulating levels of a decidual protein, placental protein 12 , in preeclampsia. Obstetrics and Gynecology 68 58-60.

Irwin JC, de las Fuentes L \& Giudice LC 1994 Growth factors and decidualization in vitro. Annals of the New York Academy of Sciences $7347-18$.

Irwin JC, Martina NA \& Giudice LC 1996 Insulin-like growth factor binding protein- 1 binds to cytotrophoblast $\alpha 5 \beta 1$ integrin and inhibits cytotrophoblast invasion into decidual multilayers. In Proceedings of the Forty-third Annual Meeting of the Society for Gynecologic Investigation, abstract 69. Philadelphia: The Society.

Iwashita M, Kudo Y, Yoshimura Y, Adachi T, Katayama E \& Takeda Y 1996 Physiological role of insulin-like-growth-factor-binding protein-4 in human folliculogenesis. Hormone Research 46 (Suppl 1) $31-36$.

Jesionowska H, Hemmings R, Guyda HJ \& Ponsner BI 1990 Determination of insulin and insulin-like growth factors in the ovarian circulation. Fertility and Sterility $\mathbf{5 3} 88-91$.

Jones JI \& Clemmons DR 1995 Insulin-like growth factors and their binding proteins: biological actions. Endocrine Reviews 16 3-34.

Jones JI, D’Ercole AJ, Camacho-Hubner C \& Clemmons DR 1991 Phosphorylation of insulin-like growth factor-binding protein in cell culture and in vivo: effects on affinity for IGF-I. Proceedings of the National Academy of Sciences of the USA 88 7481-7485.

Jones JI, Gockerman A, Busby WHJ, Camacho Hubner C \& Clemmons DR 1993a Extracellular matrix contains insulin-like growth factor binding protein-5: potentiation of the effects of IGF-I. Journal of Cell Biology 121 679-687.

Jones JI, Gockerman A, Busby WHJ, Wright G \& Clemmons DR $1993 b$ Insulin-like growth factor binding protein 1 stimulates cell migration and binds to the alpha 5 beta 1 integrin by means of its Arg-Gly-Asp sequence. Proceedings of the National Academy of Sciences of the USA 90 10553-10557.

Julkunen M, Koistinen R, Aalto-Setala K, Seppala M, Janne OA \& Kontula K 1988 Primary structure of human insulin-like growth factor binding protein/placental protein 12 and tissue specific expression of its mRNA. FEBS Letters 236 295-302.

Julkunen M, Koistinen R, Suikkari AM, Seppala M, Janne OA \& Kontula K 1990 Identification by hybridization histochemistry of human endometrial cells expressing mRNAs encoding a uterine $\beta$-lactoglobulin homologue and an insulin-like growth factor binding protein-1. Molecular Endocrinology 4 700-707.

Juul A, Scheike T, Pedersen AT, Main KM, Andersson A-M, Pedersen LM \& Skakkebaek NE 1997 Changes in serum concentrations of growth hormone, insulin, insulin-like growth factor and insulin-like growth factor-binding proteins 1 and 3 and urinary growth hormone excretion during the menstrual cycle. Human Reproduction 12 2123-2128.

Khong TY, DeWolf F, Robertson B \& Brosens I 1986 Inadequate maternal vascular response to placentation in pregnancies complicated by pre-eclampsia and by small-for-gestational age infants. British Journal of Obstetrics and Gynaecology 93 1049-1059.

Kiefer MC, Schmid C, Waldvogel M, Schlapfer I, Futo E, Masiarz FR, Green K, Barr PJ \& Zapf J 1992 Characterization of recombinant human insulin-like growth factor binding proteins 4 , 5 , and 6 produced in yeast. Journal of Biological Chemistry 267 12692-12699.

Ko Y, Choi I, Green ML, Simmen FA \& Simmen RC 1994 Transient expression of the cytochrome P450 aromatase gene in elongating porcine blastocysts is correlated with uterine insulin-like growth factor levels during peri-implantation development. Molecular Reproduction and Development 37 1-11.

Kubota T, Kamada S, Ohara M, Taguchi M, Sakamoto S, Shimizu Y \& Aso T 1993 Insulin-like growth factor II in follicular fluid of the patients with in vitro fertilization and embryo transfer. Fertility and Sterility 59 844-849.

Lai YM, Wang HS, Lee CL, Lee JD, Huang HY, Chang FH, Lee JF \& Soong YK 1996 Insulin-like growth factor-binding proteins produced by Vero cells, human oviductal cells and human endometrial cells, and the role of insulin-like growth factor-binding protein-3 in mouse embryo co-culture systems. Human Reproduction 11 1281-1286.

Lee PDK, Durham SK, Martinez V, Vasconez O, Powell DR \& Guevara-Aguirre J 1997 Kinetics of insulin-like growth factor (IGF) and IGF binding protein responses to a single dose of growth hormone. Journal of Clinical Endocrinology and Metabolism 82 2266-2274.

LeRoith D \& Roberts CT Jr 1991 Insulin-like growth factor I (IGF-I): a molecular basis for endocrine versus local action? Molecular and Cellular Endocrinology 77 C57-C61.

Ling NC, Liu XJ, Malkowski M, Guo YL, Erickson GF \& Shimasaki S 1993 Structural and functional studies of insulin-like growth factor binding proteins in the ovary. Growth Regulation 3 $70-74$.

Liu YJ, Tsushima T, Onoda N, Minei S, Sanaka M, Nagashima T, Yanagisawa K \& Omori Y 1996 Expression of messenger RNA of insulin-like growth factors (IGFs) and IGF binding proteins (IGFBP1-6) in placenta of normal and diabetic pregnancy. Endocrine Journal 43 (Suppl) S89-S91.

Magoffin DA \& Erickson GF 1988 An improved method for primary culture of ovarian androgen-producing cells in serum-free medium: effect of lipoproteins, insulin, and insulin-like growth factor I. In Vitro Cellular and Developmental Biology 24 862-870.

Magoffin DA \& Weitsman SR 1996 Synergistic interactions between LH and insulin/IGFs. In The Ovary: Regulation, Dysfunction, and Treatment, pp 79-85. Eds M Filicori \& C Flamigni. Amsterdam: Elsevier. 
Magoffin DA, Kurtz KM \& Erickson GF 1990 Insulin-like growth factor I selectively stimulates cholesterol side-chain cleavage expression in ovarian theca-interstitial cells. Molecular Endocrinology 4 489-496.

Martikainen H, Tapanainen J, Ronnberg L, Kauppila A, Selenius P \& Seppala M 1991 Insulin-like growth factor-binding protein-1 and ovarian stimulation. Human Reproduction 6 1220-1222.

Maruo T, Murata K, Matsuo H, Samoto T \& Mochizuki M 1995 Insulin-like growth factor-I as a local regulator of proliferation and differentiated function of the human trophoblast in early pregnancy. Early Pregnancy 1 54-61.

Mason HD, Margara R, Winston RM, Seppala M, Koistinen R \& Franks S 1993 Insulin-like growth factor-I (IGF-I) inhibits production of IGF-binding protein-1 while stimulating estradiol secretion in granulosa cells from normal and polycystic human ovaries. Journal of Clinical Endocrinology and Metabolism 76 1275-1279.

Mason HD, Willis DS, Holly JM \& Franks S 1994 Insulin preincubation enhances insulin-like growth factor-II (IGF-II) action on steroidogenesis in human granulosa cells. Journal of Clinical Endocrinology and Metabolism 78 1265-1267.

Mason HD, Cwyfan-Hughes SC, Heinrich G, Franks S \& Holly JM 1996 Insulin-like growth factor (IGF) I and II, IGF-binding proteins, and IGF-binding protein proteases are produced by theca and stroma of normal and polycystic human ovaries. Journal of Clinical Endocrinology and Metabolism 81 276-284.

Meekins JW, Pijnenborg R, Hanssens M, McFayden IR \& van Assche A 1994 A study of placental bed spiral arteries and trophoblast invasion in normal and severe preeclamptic pregnancies. British Journal of Obstetrics and Gynaecology 101 669-674.

Mesiano S, Katz SL, Lee JY \& Jaffe RB 1997 Insulin-like growth factors augment steroid production and expression of steroidogenic enzymes in human fetal adrenal cortical cells: implications for adrenal androgen regulation. Journal of Clinical Endocrinology and Metabolism 82 1390-1396.

Mohan S, Bautista CM, Wergedal J \& Baylink DJ 1989 Isolation of an inhibitory insulin-like growth factor (IGF) binding protein from bone cell-conditioned medium: a potential local regulator of IGF action. Proceedings of the National Academy of Sciences of the USA 86 8338-8342.

Morgan DO, Edman JC, Standring DN, Fried VA, Smith MC, Roth RA \& Rutter WJ 1987 Insulin-like growth factor II receptor as a multifunctional binding protein. Nature 329 301-307.

Nagamani M \& Stuart CA 1990 Specific binding sites for insulin-like growth factor I in the ovarian stroma of women with polycystic ovarian disease and stromal hyperthecosis. American Journal of Obstetrics and Gynecology 163 1992-1997.

Nahum R, Thong KJ \& Hillier SG 1995 Metabolic regulation of androgen production by human thecal cells in vitro. Human Reproduction 10 75-81.

Nissley P \& Lopaczynski W 1991 Insulin-like growth factor receptors. Growth Factors 5 29-43.

Nobels F \& Dewailly D 1992 Puberty and polycystic ovarian syndrome: the insulin/insulin-like growth factor I hypothesis. Fertility and Sterility $\mathbf{5 8}$ 655-666.

Ocrant I, Valentino KL, Eng LF, Hintz RL, Wilson DM \& Rosenfeld RG 1988 Structural and immunohistochemical characterization of insulin-like growth factor I and II receptors in the murine central nervous system. Endocrinology 123 1023-1034.

Oliver JE, Aitman TJ, Powell JF, Wilson CA \& Clarton RN 1989 Insulin-like growth factor I gene expression in the rat ovary is confined to the granulosa cells of developing follicles. Endocrinology 124 2671-2679.

Ostlund E, Bang P, Hagenas L \& Fried G 1997 Insulin-like growth factor I in fetal serum obtained by cordocentesis is correlated with intrauterine growth retardation. Human Reproduction 12 840-844.
Pekonen F, Suikkari A-M, Makinen T \& Rutanen E-M 1988 Different insulin-like growth factor species in human placenta and decidua. Journal of Clinical Endocrinology and Metabolism 67 $1250-1257$.

Pekonen F, Nyman T, Lahteenmaki P, Haukkamaa M \& Rutanen E-M 1992 Intrauterine progestin induces continuous insulin-like growth factor binding protein-1 production in the human endometrium. Journal of Clinical Endocrinology and Metabolism 75 660-664.

Pellegrini S, Fuzzi B, Pratesi S, Mannelli M, Criscuoli L, Messeri G \& Forti G 1995 In vivo studies on ovarian insulin-like growth factor I concentrations in human preovulatory follicles and human ovarian circulation. Human Reproduction 10 1341-1345.

Peng X, Maruo T, Samoto T \& Mochizuki M 1996 Comparison of immunocytologic localization of insulin-like growth factor binding protein-4 in normal and polycystic ovary syndrome human ovaries. Endocrine Journal 43 269-278.

Penhoat A, Jaillard C \& Saez JM 1989 Synergistic effects of corticotropin and insulin-like growth factor I on corticotropin receptors and corticotropin responsiveness in cultured bovine adrenocortical cells. Biochemical and Biophysical Research Communications 165 355-359.

Poretsky L, Chandrasekher YA, Bai C, Liu HC, Rosenwaks Z \& Giudice L 1996 Insulin receptor mediates inhibitory effect of insulin, but not of insulin-like growth factor (IGF)-I, on IGF binding protein-1 (IGFBP-1) production in human granulosa cells. Journal of Clinical Endocrinology and Metabolism $\mathbf{8 1}$ 493-496.

Quinn LS, Ehsan M, Steinmetz B \& Kaleko M 1993 Liganddependent inhibition of myoblast differentiation by overexpression of the type-I insulin-like growth factor receptor. Journal of Cell Physiology 156 453-461.

Reeve JG, Schwander J \& Bleehen NM 1993 IGFBP-2: an important regulator of insulin-like growth factor action in human lung tumors. Growth Regulation 3 82-84.

Rinderknecht E \& Humbel RE 1978a The amino acid sequence of human insulin-like growth factor-I and its structural homology with proinsulin. Journal of Biological Chemistry 253 2769-2776.

Rinderknecht E \& Humbel RE 1978 b Primary structure of human insulin-like growth factor II. FEBS Letters 89 283-286.

Ritvos O, Ranta T, Jalkanen J, Suikkari A-M, Voutilainen R, Bohn H \& Rutanen EM 1988 Insulin-like growth factor (IGF) binding protein from human decidua inhibits the binding and biological action of IGF-I in cultured choriocarcinoma cells. Endocrinology 122 2150-2157.

Robertson WB 1976 Utero-placental vasculature. Journal of Clinical Pathology 9 (Suppl 10) 9-17.

Rohan RM, Ricciarelli E, Kiefer MC, Resnik CE \& Adashi EY 1993 Rat ovarian insulin like growth factor binding protein-6: a hormonally regulated theca-interstitial-selective species with limited antigonadotropic activity. Endocrinology 132 2507-2512.

Rosenfeld RG 1989 Receptors for insulin-like growth factors I and II. In Advances in Growth Hormone and Growth Factor Research, pp 133-168. Eds EE Miller, D Cocchi \& V Locatelli. Rome: Pythagora Press.

Rutanen E-M \& Pekonen F 1991 Insulin-like growth factor binding protein-1 in human endometrial function. In Modern Concepts of Insulin-Like Growth Factors, pp 285-294. Ed EM Spencer. New York: Elsevier.

Rutanen E-M, Pekonen F \& Makinen T 1988 Soluble 34K binding protein inhibits the binding of insulin-like growth factor I to its cell receptors in human secretory phase endometrium: evidence for autocrine/paracrine regulation of growth factor action. Journal of Clinical Endocrinology and Metabolism 66 173-180.

Rutanen E-M, Gonzales E, Said J \& Braunstein GD 1991 Immunohistochemical localization of the insulin-like growth factor binding protein-1 in female reproductive tissues by monoclonal antibodies. Endocrine Pathology 2 132-138. 
Rutanen E-M, Pekonen F, Nyman T \& Wahlstrom T 1993 Insulinlike growth factors and their binding proteins in benign and malignant uterine diseases. Growth Regulation 3 72-75.

Sakai K, Iwashita M \& Takeda Y 1997 Profiles of insulin-like growth factor binding proteins and the protease activity in the maternal circulation and its local regulation between placenta and decidua. Endocrine Journal 44 409-417.

San Roman GA \& Magoffin DA 1993 Insulin-like growth factor binding proteins in healthy and atretic follicles during natural menstrual cycles. Journal of Clinical Endocrinology and Metabolism 76 625-632.

Sarvas K, Angervo M, Koistinen R, Tiitinen A \& Seppala M 1994 Prostaglandin F2 alpha stimulates release of insulin-like growth factor binding protein-3 from cultured human granulosa-luteal cells. Human Reproduction 9 1643-1646.

Schmid C, Rutishauser J, Schlapfer I, Froesch ER \& Zapf J 1991 Intact but not truncated insulin-like growth factor binding protein-3 (IGFBP-3) blocks IGF-I-induced stimulation of osteoblasts: control of IGF signalling to bone cells by IGFBP-3specific proteolysis? Biochemical and Biophysical Research Communications 179 579-585.

Schoenle E, Zapf J, Hauri C, Steiner T \& Froesch ER 1985 Comparison of in vivo effects of insulin-like growth factor-I and -II and of growth hormone in hypophysectomized rats. Acta Endocrinologica 108 167-174.

Schwander JC, Hauri C, Zapf J \& Froecsh ER 1983 Synthesis and secretion of insulin-like growth factor and its binding protein by the perfused rat liver: dependence on growth hormone status. Endocrinology 113 297-305.

Seleem S, Hills FA, Salem HT, El-Nashar EM \& Chard T 1996 Mechanism of action of the intrauterine contraceptive device: evidence for a specific biochemical deficiency in the endometrium. Human Reproduction 11 1220-1222.

Shi CZ, Collin HW, Buettger CW, Garside WT, Matschinsky FM \& Heyner S 1994 Insulin family growth factors have specific effects on protein synthesis in preimplantation mouse embryos. Molecular Reproduction and Development 37 398-406.

Smith RM, Garside WT, Aghayan M, Shi CZ, Shah N, Jarett L \& Heyner S 1993 Mouse preimplantation embryos exhibit receptormediated binding and transcytosis of maternal insulin-like growth factor I. Biology of Reproduction 49 1-12.

Straus DS, Ooi GT, Orlowski CC \& Rechler MM 1991 Expression of the genes for insulin-like growth factor-I (IGF-I), IGF-II, and IGF-binding proteins-1 and -2 in fetal rat under conditions of intrauterine growth retardation caused by maternal fasting. Endocrinology 128 518-525.

Strowitzki T, Singer GA, Rettig I \& Capp E 1996 Characterization of receptors for insulin-like growth factor type I on cultured human endometrial stromal cells: downregulation by progesterone. Gynecological Endocrinology 10 229-240.

Suhonen S, Haukkamaa M, Holmstrom T, Lahteenmaki P \& Rutanen EM 1996 Endometrial response to hormone replacement therapy as assessed by expression of insulin-like growth factor-binding protein-1 in the endometrium. Fertility and Sterility 65 776-782.

Suikkari A-M, Seppala M, Tiitinen A, Laatikainen T \& Stenman U-H 1991 Oral contraceptives increase insulin-like growth factor binding protein-1 concentration in women with polycystic ovarian disease. Fertility and Sterility 55 895-899.

Suvanto-Luukkonen E, Sundstrom H, Penttinen J, Kauppila A \& Rutanen EM 1995 Insulin-like growth factor-binding protein-1: a biochemical marker. of endometrial response to progestin during hormone replacement therapy. Maturitas 22 255-262.

Than GN, Csaba IF, Szabo DG, Arany AA, Bognar ZJ \& Bohn H 1984 Serum levels of placental-specific tissue protein 12 (PP12) in pregnancy complicated by pre-eclampsia, diabetes, or twins. Archives of Gynecology 236 41-45.

Thierry van dessel HJHM, Chandrasekher Y, Stephanie Yap OW, Lee PDK, Hintz RL, Faessen GHJ, Braat DDM, Fauser BCJM \& Giudice LC 1996 Serum and follicular fluid levels of insulin-like growth factor I (IGF-I), IGF-II, and IGF-binding protein-1 and -3 during the normal menstrual cycle. Journal of Clinical Endocrinology and Metabolism 81 1224-1231.

Wang HS \& Chard T 1992 Chromatographic characterization of insulin-like growth factor-binding proteins in human pregnancy serum. Journal of Endocrinology 133 149-159.

Wang HS \& Soong YK 1996 Transvaginal progesterone supplementation increases serum levels of insulin-like growth factor-binding protein-1. Gynecological Endocrinology 10 349-355.

Wang HS, Perry LA, Kanisius J, Iles RK, Holly JMP \& Chard T 1991 Purification and assay of insulin-like growth factor-binding protein-1: measurement of circulating levels throughout pregnancy. Journal of Endocrinology 128 161-168.

Wang HS, Lee JD \& Soong YK 1995 Serum levels of insulin-like growth factor-I and insulin-like growth factor-binding protein-1 and -3 in women with regular menstrual cycles. Fertility and Sterility 63 1204-1209.

Wang HS, Lee JD, Cheng BR \& Soong YK 1996 Insulin-like growth factor-binding protein-1 and insulin-like growth factor-binding protein-3 in pre-eclampsia. British Journal of Obstetrics and Gynaecology 103 654-659.

Weaver JU, Holly JMP, Kopelman PG, Noonan K, Giadom CG, White N, Virdee S \& Wass JA 1990 Decreased sex hormone binding globulin (SHBG) and insulin-like growth factor binding protein (IGFBP-1) in extreme obesity. Clinical Endocrinology 33 415-422.

Yoeh SI \& Baxter RC 1988 Metabolic regulation of the growth hormone independent insulin-like growth factor-binding protein in human plasma. Acta Endocrinologica 119 465-473.

Zapf J, Walter H \& Froesch ER 1981 Radioimmunological determination of insulin-like growth factors I and II in normal subjects and in patients with growth disorders and extrapancreatic tumor hypoglycemia. Journal of Clinical Investigation 68 13211330.

Zhou J \& Bondy C 1993 Anatomy of the human ovarian insulin-like growth factor system. Biology of Reproduction 48 467-482.

Zhou J, Chin E \& Bondy C 1991 Cellular pattern of insulin-like growth factor I (IGF-I) and IGF-I receptor gene expression in the developing and mature ovarian follicle. Endocrinology 129 3281-3288.

Zhou J, Dsupin BA, Giudice LC \& Bondy CA 1994 Insulin-like growth factor system gene expression in human endometrium during the menstrual cycle. Journal of Clinical Endocrinology and Metabolism 79 1723-1734.

Received 22 December 1997

Revised manuscript received 20 April 1998

Accepted 10 September 1998 